University of Nebraska - Lincoln

DigitalCommons@University of Nebraska - Lincoln

\title{
Simulated Effects Of Host Fish Distribution On Juvenile Unionid Mussel Dispersal In A Large River
}

J. A. Daraio

University of lowa, joseph.a.daraio@gmail.com

L. J. Weber

University of lowa, larry-weber@uiowa.edu

Steven J. Zigler

USGS, szigler@usgs.gov

Teresa J. Newton

USGS, tnewton@usgs.gov

John M. Nestler

US Army Engineer Research and Development Center, john.m.nestler@erdc.usace.army.mil

Follow this and additional works at: https://digitalcommons.unl.edu/usgsstaffpub

Daraio, J. A.; Weber, L. J.; Zigler, Steven J.; Newton, Teresa J.; and Nestler, John M., "Simulated Effects Of Host Fish Distribution On Juvenile Unionid Mussel Dispersal In A Large River" (2012). USGS Staff -Published Research. 591.

https://digitalcommons.unl.edu/usgsstaffpub/591

This Article is brought to you for free and open access by the US Geological Survey at DigitalCommons@University of Nebraska - Lincoln. It has been accepted for inclusion in USGS Staff -- Published Research by an authorized administrator of DigitalCommons@University of Nebraska - Lincoln. 


\title{
SIMULATED EFFECTS OF HOST FISH DISTRIBUTION ON JUVENILE UNIONID MUSSEL DISPERSAL IN A LARGE RIVER
}

\author{
J. A. DARAIO, ${ }^{\mathrm{a} *}$ L. J. WEBER, ${ }^{\mathrm{a}}$ S. J. ZIGLER, ${ }^{\mathrm{b}}$ T. J. NEWTON ${ }^{\mathrm{b}}$ and J. M. NESTLER ${ }^{\mathrm{c}}$

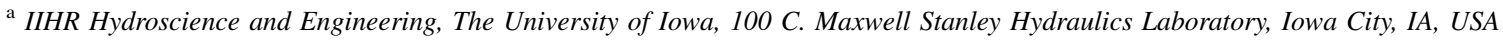 \\ ${ }^{\mathrm{b}}$ USGS, Upper Midwest Environmental Sciences Center, La Crosse, WI, USA \\ ${ }^{\mathrm{c}}$ US Army Engineer Research and Development Center, Vicksburg, MS, USA
}

\begin{abstract}
Larval mussels (Family Unionidae) are obligate parasites on fish, and after excystment from their host, as juveniles, they are transported with flow. We know relatively little about the mechanisms that affect dispersal and subsequent settlement of juvenile mussels in large rivers. We used a three-dimensional hydrodynamic model of a reach of the Upper Mississippi River with stochastic Lagrangian particle tracking to simulate juvenile dispersal. Sensitivity analyses were used to determine the importance of excystment location in two-dimensional space (lateral and longitudinal) and to assess the effects of vertical location (depth in the water column) on dispersal distances and juvenile settling distributions. In our simulations, greater than $50 \%$ of juveniles mussels settled on the river bottom within $500 \mathrm{~m}$ of their point of excystment, regardless of the vertical location of the fish in the water column. Dispersal distances were most variable in environments with higher velocity and high gradients in velocity, such as along channel margins, near the channel bed, or where effects of river bed morphology caused large changes in hydraulics. Dispersal distance was greater and variance was greater when juvenile excystment occurred in areas where vertical velocity $(w)$ was positive (indicating an upward velocity) than when $w$ was negative. Juvenile dispersal distance is likely to be more variable for mussels species whose hosts inhabit areas with steeper velocity gradients (e.g. channel margins) than a host that generally inhabits low-flow environments (e.g. impounded areas). Copyright (C) 2010 John Wiley \& Sons, Ltd.
\end{abstract}

KEY WORDS: ecohydraulics; host fish; spatial distribution; transport; unionids

Received 30 March 2010; Revised 31 August 2010; Accepted 23 September 2010

\section{INTRODUCTION}

Mussels of the family Unionidae (unionids) have an obligate parasitic larval stage that requires a fish host. Females release larvae, or 'glochidia,' that remain attached to the gills and fins of fishes until they metamorphose into juveniles and are released (excyst) from the host fish. Dispersal is a vital aspect of mussel ecology that connects subpopulations and allows for the maintenance of metapopulations (Strayer, 2008). Adult mussels have relatively restricted rates of dispersal (e.g. 10's of meters; Balfour and Smock 1995; Amyot and Downing 1998; Villella et al. 2004; Schwalb and Pusch 2007) consequently, dispersal of unionid mussels largely occurs while in the parasitic stage when attached to their host fish, and most long range or upstream transport is accomplished during the parasitic stage.

After excystment from the host fish, dispersal occurs via transport with flow, and the fluid environment may be significant in structuring spatial patterns of juvenile mussel settlement (Hart and Finelli, 1999). Dams, which have significantly affected unionid habitat, act as barriers to fish

*Correspondence to: J. A. Daraio, U.S. Geological Survey, 12201 Sunrise Valley Drive, MS 436, Reston, VA 20192.

E-mail: joseph.a.daraio@gmail.com migration that likely have significant effects on unionid populations (Watters, 1996; Brainwood et al., 2008), and are in part responsible for the imperiled status of unionids in North America (Lydeard et al., 2004; Strayer et al., 2004). Little is known about what processes are most important and how they function to set limits on mussel population distributions (Vaughn and Taylor, 2000; Strayer et al., 2004; Newton et al., 2008; Strayer, 2008). It is likely that the spatial distribution of host fish influences the spatial patterns of mussels. However, it is not clear if and to what extent hydraulic conditions at the point of juvenile excystment from the host fish influence the final settling location of juvenile mussels.

Much of the research on the relationship between native mussels and their host fish generally concerns the importance of host fishes in structuring adult mussel assemblages. Watters (1992) has shown that there is a linear relationship between the number of host fish species and the number of mussel species in a drainage basin. Regional scale processes and nestedness in spatial patterns of mussel communities have been linked to their host fish requirements (Vaughn, 1997). At the basin scale, variation in host fish community distribution has been correlated with variation in mussel community distribution (Haag and 
Warren, 1998). Vaughn and Taylor (2000) found that $>50 \%$ of the variation in mussel assemblages was explained by the distribution and abundance of fishes in the Red River drainage basin (Oklahoma, Texas and Arkansas), and that host fish distribution was a strong determinate of mussel assemblage structure. Vaughn and Taylor (2000) also found that sites with high fish species richness showed a wide range of mussel species richness, but sites with low fish species richness always had low mussel species richness. These patterns may be, in part, a result of a mussel species ability to infect a host that can result in different colonization potentials among mussel species (Vaughn, 1997; Rashleigh and DeAngelis, 2007; Rashleigh, 2008). However, these findings are often difficult to interpret. Stream size may be a factor since benthic invertebrate species richness tends to increase from headwater to mid-order streams (Minshall et al., 1985), and mussel species richness is related to stream size (Gangloff and Feminella, 2007). Additionally, environmental constraints at smaller scales will provide a limit to the mussel species richness at a given site, even if dispersal by host fish is high (Vaughn and Taylor, 2000). Correspondingly, if dispersal from fish is low then presumably there will be fewer species of mussels regardless of the quality of habitat at the river bed.

Relatively less is known about the juvenile life stage, and most of the major movement $(>10 \mathrm{~m})$ in mussels likely occurs in their early life stages: attached larvae on a host fish, passive movement of larvae in the water column and movement of juveniles across the river bed (Newton et al., 2008). In particular, we do not know the hydraulic mechanisms that influence the dispersal and subsequent establishment of juvenile mussels on the river bed. In marine systems, the settling density of larval clams was determined by upstream hydraulic conditions, flow history and larval behaviour (Crimaldi et al., 2002; North et al., 2008). For juvenile unionids in rivers, upstream conditions are dependent upon river morphology and the lateral, longitudinal and vertical location in the water column of their host fish at the time of excystment. The sensitivity of juvenile dispersal to initial excystment location likely depends directly on hydraulic conditions in the area of excystment. Relatively small changes in location of juveniles at excystment may have a significant effect on the distribution of settled juveniles because hydraulic conditions can change substantially over small scales in rivers.

Morales et al. (2006a) modelled juvenile dispersal in a reach of the Upper Mississippi River (UMR) using 2D hydrodynamic models that did not fully account for variation in hydraulic patterns in the water column. They assumed that juveniles excysted at the water surface, and they did not analyse the effects of flow conditions at the location of excystment on settling of juveniles. Daraio et al. (2010b) extended the juvenile dispersal model developed by
Morales et al. (2006b) to include excystment at various depths with the use of a three-dimensional (3D) hydrodynamic model of a reach of the UMR. The dispersal model is a virtual laboratory for simulating juvenile dispersal that allowed us to isolate the effects of hydraulic conditions in the water column from near bed hydraulics, such as shear stress, on dispersal. Daraio et al. (2010a) used the model to show that bed shear stress can potentially have significant effects on juvenile dispersal distance and settling distribution.

We examined the effects of location of the host fish and the hydraulic conditions where juvenile excystment occurs on the settling distributions of juveniles, without the effects of bed shear stress. We hypothesized that variation in juvenile dispersal distance after excystment from its host fish is dependent upon velocity of flow and gradients in velocity at the location of excystment. We explored the relationship between initial excystment location and final juvenile settling distributions using two sensitivity analyses. We examined the sensitivity of dispersal distance and settling distribution on (1) host fish location in 2D space (lateral and longitudinal), and (2) vertical location (depth in the water column) of host fish at time of juvenile excystment.

\section{METHODS}

\section{Study site}

A system of locks and dams in the Upper Mississippi River, beginning north of St. Louis, Missouri and extending to St. Paul, Minnesota, maintains a $2.7 \mathrm{~m}$ deep navigation channel that creates a system of navigation pools, numbered from north to south. Juvenile dispersal modelling was done in Navigation Pool 13 (hereafter Pool 13), a 50-km reach extending from Lock and Dam 13 at Clinton, Iowa north to Bellevue, Iowa (Figure 1). We modelled the lower $23 \mathrm{~km}$ of the pool. The lower $13 \mathrm{~km}$ of the modelled reach are considered impounded areas-characterized by wide (typically $>5 \mathrm{~km})$ and shallow $(<2 \mathrm{~m})$ areas containing many backwater habitats (except for the main navigation channel). The upper $10 \mathrm{~km}$ of the modelled reach is narrow $(<1.5 \mathrm{~km}$ wide $)$, and is separated from its floodplain by levees on both sides of the channel. As a result, this upper part of the modelled reach is more channelized with little or no areas of impoundment or backwater.

We chose this reach because it is part of the Long Term Resource Monitoring Programme (LTRMP), which is implemented as a partnership of federal and state agencies. The LTRMP collects data on numerous biological components of this UMR ecosystem; we used their extensive fisheries data to identify the spatial location of host fishes for mussels (see below). Also, the morphology of the pool, with 


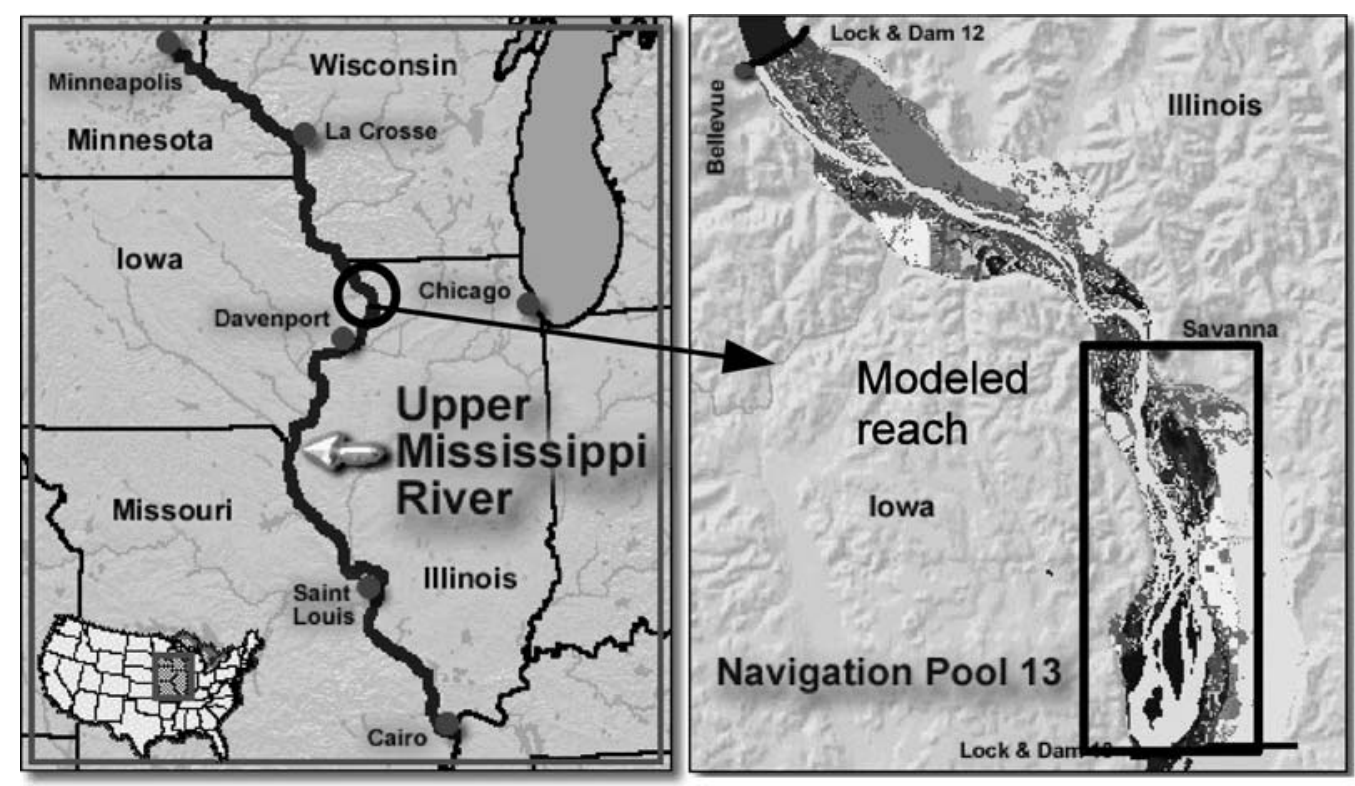

Figure 1. Location of Pool 13 of the Upper Mississippi River. We modelled the lower $23 \mathrm{~km}$ of this reach (images: http://www.umesc.usgs.gov/rivers.html)

a large impounded area and a channelized free flowing area, provides a wide range of hydraulic conditions for a sensitivity analysis.

\section{Hydrodynamic modelling}

A 3D computational fluid dynamics (CFD) model was used to simulate flow in Pool 13 (Appendix). The flow field describing the hydrodynamics from the steady-state solution at $1415 \mathrm{~m}^{3} \mathrm{~s}^{-1}$ was used to represent the average annual daily flow at Lock and Dam 13. The computational mesh used in the CFD model had about 1.9 million nodes, with 15 layers in the vertical dimension. For practical purposes the mesh used in CFD modelling was not used for the dispersal simulations. Our dispersal mesh was three dimensional consisting of a uniform orthogonal planar 2D (x, y) 10 by $25 \mathrm{~m}$ grid with 15 vertical (z) layers ( $\sim 2.4$ million nodes), which was used for particle tracking. The vertical grid representing depth of flow was non-uniform and nonorthogonal with nodes located as a proportion of total depth and a greater concentration of nodes near the river bed (Figure 2). Juveniles were modelled individually using a stochastic Lagrangian particle tracking method (Appendix).

\section{Model assumptions for juvenile settling}

There is no evidence that juvenile mussels actively swim. Juveniles may have some control over drag by extending their foot during settling, but the effects of this behaviour are likely only important at small scales (Schwalb, 2009). Therefore, we assumed that juveniles settled as passive particles following Stoke's law, which is given by

$$
\omega=-\frac{S F}{18 v}\left(S G_{\mathrm{juv}}-1\right) g d^{2}
$$

where $d$ is particle diameter $(\mathrm{m}), v$ is the kinematic viscosity of water $\left(\mathrm{m} \mathrm{s}^{-1}\right), g$ is the gravitational acceleration $\left(\mathrm{m} \mathrm{s}^{-2}\right)$, $S G$ is the specific gravity of juvenile mussels, and the shape factor is

$$
S F=c(a b)^{-1 / 2}
$$

where $a, b$, and $c$ are the lengths of the longest, intermediate, and shortest mutually orthogonal axes through the particle. Parameters for calculating fall velocity were obtained from published literature where possible. Specific gravity values were randomly selected from a uniform distribution, varying between 1.18 and 1.22, based on data on juvenile Actinonaias ligamentina (A. Schwalb, pers. comm.). Length and width of juvenile mussels were taken from Stein (1973) based on measurements of Amblema plicata, and based on these data we assumed that $S F$ varies uniformly between 0.5 and 0.8 . The dispersal model was validated in pool 13 by Daraio et al. (2010b) where it was shown that the physical processes describing the hydraulics of flow were fully captured.

\section{Model output}

Spatial coordinates $(x, y, z)(\mathrm{m})$, the three components of velocity $(u, v, w)\left(\mathrm{m} \mathrm{s}^{-1}\right)$, and the turbulent kinetic energy $(k)$ $\left(\mathrm{kg} \mathrm{m} \mathrm{s}^{-1}\right)$ from CFD results were interpolated onto the 3D 


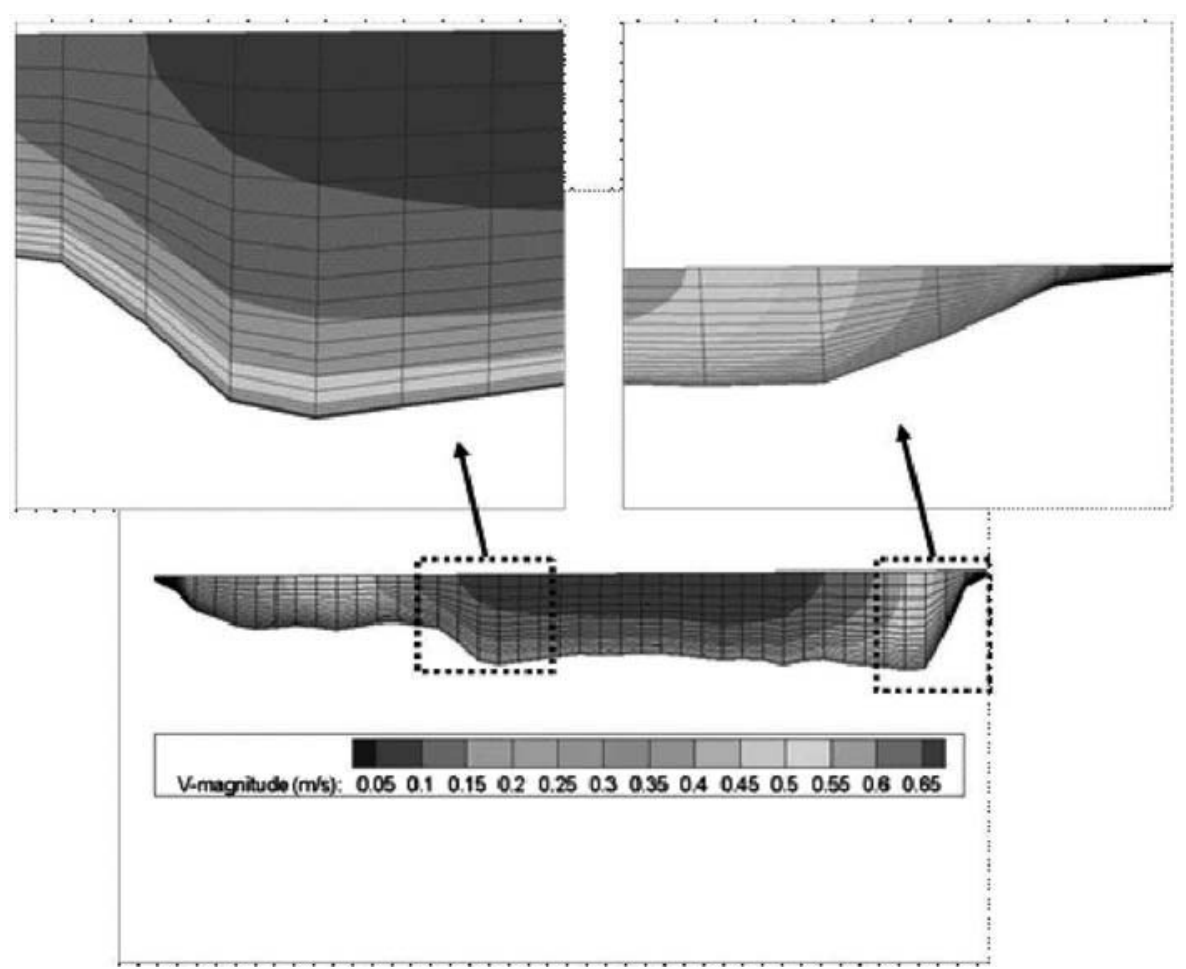

Figure 2. Arbitrary cross section of a section of the mesh showing the 15 vertical layers of the dispersal mesh. Contours show the velocity magnitude over the cross section with the greatest velocities in the centre of the channel near the water surface and greater rates of change in velocity near the river bed. The concentration of computational nodes is greater near the river bed where gradients in velocity are greater

dispersal mesh using inverse distance weighting (Shepard's method). The magnitude of velocity gradients $\left(V_{g}\right)$ $\left(\mathrm{m} \mathrm{s}^{-1} \mathrm{~m}^{-1}\right)$ were calculated for each grid cell using data at nodes bordering each cell, and were calculated with velocity magnitude in $2 \mathrm{D}$ (across river and streamwise) as

$$
V_{g}=\sqrt{\left(\frac{\Delta u}{\Delta y}\right)^{2}+\left(\frac{\Delta v}{\Delta x}\right)^{2}}
$$

Magnitudes of vertical velocity gradients were calculated as $W_{g}=V_{l}-V_{l-1}$ where $V_{l}$ is the average $2 \mathrm{D}$ velocity magnitude in a grid cell at layer $l$ of the mesh $\left(V_{l-1}\right.$ is at the layer below $l$ ).

Multiple dispersal simulations were run to estimate likelihood of juvenile settling in each grid cell using the parameter of a Poisson distribution $(\lambda)$ (see Daraio et al., 2010b). Maximum likelihood estimation was used to estimate $\lambda$, which is given by

$$
\lambda=\frac{\sum_{i}^{N} m_{i}^{\text {cell }}}{N}
$$

where $m$ is the number of individuals that settled in a cell, and $N$ is the number of simulations. Contours maps of $\lambda$ values were used to show the spatial distribution of the likelihood of juvenile settling in Pool 13. Maps of $\lambda$ and velocity were created using Tecplot 360 (2008, Tecplot, Inc., Bellevue, WA). Dispersal distances of juveniles were output from simulations, and the non-parametric Mann-Whitney test was used to test for differences $(p<0.05$, unless otherwise indicated) in dispersal distances. The $\mathrm{R}$ statistical package was used for all analyses ( $\mathrm{R}$ version 2.9.0/17 April 2009, The R Foundation for Statistical Computing, Vienna).

\section{Host fish data and assumptions}

The threeridge mussel (Amblema plicata) is a common species in the UMR and was used as a representative mussel in our model. Adult A. plicata generally spawn in the spring and release glochidia from April to mid-August (Lefevre and Curtis, 1910; Parmalee and Bogan, 1998). It has a wide distribution, and there are data available on its life history and host fish requirements. We used the USGS fisheries database browser (USGS, 2009a) to access spatial locations, water depth and total count for host fish for A. plicata in Pool 13 (Table I) sampled at random locations with a variety of gear types (see Gutreuter et al., 1995) during June through August, from 1989 to 2007. LTRMP sampling includes major aquatic types: channel borders, backwaters and impounded areas, but little sampling is done in the main navigation channel. All data were used to provide a range of 
Table I. Known host fish for Amblema plicata that reside in Pool 13 of the Upper Mississippi River and their presence and timing in the main navigation channel ( $\mathrm{NF}=$ not found). Host fish species were determined using the host-parasite database at Ohio State University (www.biosci.ohio-state.edu/ molluscs/OSUMZ/) using only laboratory infestations where metamorphosis was observed.

\begin{tabular}{lll}
\hline Host fish species & Scientific name & $\begin{array}{l}\text { Presence in } \\
\text { main channel }\end{array}$ \\
\hline Rock Bass & Ambloplites rupestris & $\mathrm{NF}$ \\
Shortnose Gar & Lepisosteus oculatus & (Autumn) \\
Green Sunfish & Lepomis cyanellus & $\mathrm{NF}$ \\
Pumpkinseed & Lepomis gibbosus & $\mathrm{NF}$ \\
Bluegill & Lepomis macrochirus & $\mathrm{NF}$ \\
Largemouth Bass & Micropterus salmoides & $\mathrm{NF}$ \\
Yellow Perch & Perca flavescens & $\mathrm{NF}$ \\
White Crappie & Pomoxis annularis & $\mathrm{NF}$ \\
Black Crappie & Pomoxis annularis & (Autumn) \\
\hline
\end{tabular}

locations for host fish, which we believe is justified because the uncertainty was incorporated as part of the sensitivity analyses.

We accounted for limitations in the host fish data by using information in the existing literature on fish distributions in the UMR to develop the range of model scenarios for the sensitivity analyses. Our host distribution assumptions were verified by numerous studies in the UMR (Dewey et al., 1997; Johnson and Jennings, 1998; Dettmers et al., 2001; Chick et al., 2005). We used the USGS fisheries data browser (USGS, 2009a) to plot the frequency of water depths where

A1

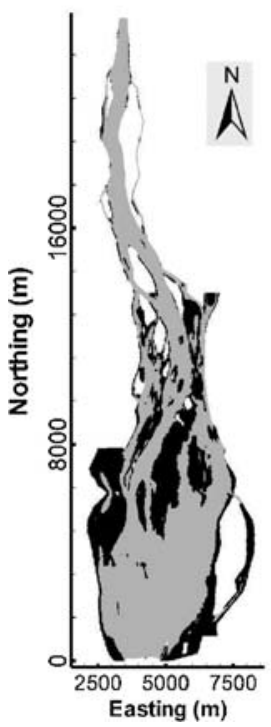

A2

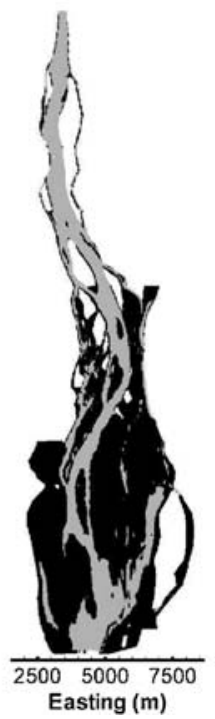

A3

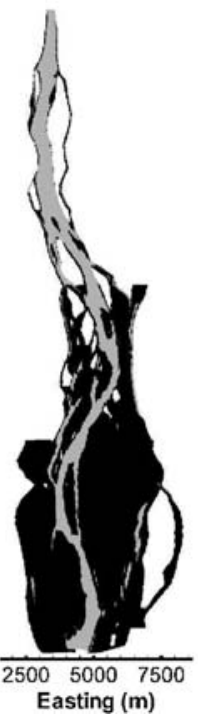

host fish for A. plicata were found-this analysis suggests that $>97 \%$ of the species were present at depth $\leq 2 \mathrm{~m}$. Based on these data and perceived habitat associations from the literature, we assumed that host fish were unlikely to occur in grid cells with a depth $>2.0 \mathrm{~m}$, and channel habitats were assumed to be grid cells with depths $>2 \mathrm{~m}$ in the sensitivity analyses.

\section{Sensitivity analyses}

Sensitivity analyses were performed to assess the effects of location and hydraulic conditions when juveniles excyst from their host fish on final settling location. Two scenarios were explored. In scenario A, the longitudinal (y) and lateral location ( $x$ ) within the river at the time of juvenile excystment from their host fish was varied, and excystment depths were the same for each simulation. In scenario B, depth $(\mathrm{z})$ of excystment was varied. In all simulations, one juvenile was released in the centre of each cell, and juvenile mussels were assumed to settle where they first contacted the riverbed. The latter assumption effectively isolated the effects of hydraulics within the water column by ignoring hydraulic processes that occur at the river bed.

\section{Scenario A}

Six sets of simulations were run with the following initial conditions (Figure 3). In scenarios A1-A4, juvenile excystment was assumed to occur at water depths of $<1.0,<1.5,<2.0$ and $>2.0 \mathrm{~m}$, respectively, with the latter representing excystment in channel habitats. In scenario A5,

Figure 3. Initial excystment areas (black) of juveniles modelled in each simulation. A1-A4: juveniles assumed to excyst in cells with water depth $<1.0,<1.5$, $<2.0$ and $>2.0 \mathrm{~m}$, respecitively; A5: juveniles assumed to excyst in cells based on coordinate locations based on data on host fish from the USGS fisheries database (USGS, 2009a); A6: juveniles assumed to excyst in every cell within the domain 
Table II. Summary of excystment depths for juvenile Amblema plicata in model simulations in Pool 13 of the Upper Mississippi River. Excystment depth was determined as a proportion of the total water depth. Excystment depths for scenario A are in bold; all excystment depths are used in scenario B

\begin{tabular}{ll}
\hline Vertical location & $\begin{array}{l}\text { Proportion of } \\
\text { total water depth }\end{array}$ \\
\hline 1 (near river bed) & 0.001 \\
2 & 0.01 \\
3 & 0.02 \\
4 & 0.03 \\
$\mathbf{5}$ & $\mathbf{0 . 0 4}$ \\
6 & 0.05 \\
$\mathbf{7}$ & $\mathbf{0 . 7 5}$ \\
8 & 0.1 \\
$\mathbf{9}$ & $\mathbf{0 . 2}$ \\
10 & 0.3 \\
$\mathbf{1 1}$ & $\mathbf{0 . 4}$ \\
$\mathbf{1 3}$ & 0.5 \\
14 & $\mathbf{0 . 6}$ \\
15 (at water surface) & 0.75 \\
\hline
\end{tabular}

juvenile excystment was based on spatial locations of host fish presence from the LTRMP fisheries database (USGS, 2009a) using pooled data from 1989 to 2007. At locations with a fish count $>1$, fish were distributed around the $x$ and $y$ coordinates using a normal distribution with $\mu_{x}=\mu_{y}=0 \mathrm{~m}$, and standard deviations $\sigma_{x}$ and $\sigma_{y}$ were assumed independent. Simulations were run with $\sigma_{x}=1,15,30$ and $45 \mathrm{~m}$ and $\sigma_{y}=100 \mathrm{~m}$, which provided some local spatial variation of excystment so as not to assume that all juvenile excystment occurred from the same point location. In scenario A6, juvenile excystment was in every cell in the domain. In each set of simulations, juveniles were assumed to excyst at five water depths as a proportion of the total water depth $(H)$ in a cell (Table II and Figure 2). A total of 500 dispersal events (100 at each depth of excystment) were modelled in each set of simulations, except simulations A5, which included 2000 dispersal events (i.e. 500 dispersal events for each of the four simulations of fish distributions).

\section{Scenario B}

Juveniles were assumed to excyst from cells with water depth $<2 \mathrm{~m}$ (to exclude excystment in channel habitats, same as A3; Figure 3); excystment depth was varied across all 15 vertical locations of the dispersal mesh (simulations B1). Depth of excystment was set as a distance from the channel bed proportional to water depth within a cell (Table II). The actual depth of excystment was variable based on the depth of water in the cell while the percentage of total depth was the same in all grid cells (see Figure 2). Simulations B2 were run with initial excystment areas determined from the spatial location of host fish from the USGS fisheries database (as in A5), and excystment depth was varied across all 15 vertical locations, as in B1.

\section{RESULTS}

There was a decline in the number of juveniles that settled as distance from the point of excystment increased in all simulations. The rate of decrease of dispersal distance was related to the velocity of flow at the excystment location, with a slower decrease when excystment occurred in high velocity areas, such as in or near the main channel. Variation of juvenile dispersal distance was greater when excystment was in areas with steeper gradients in velocity. Area with steeper velocity gradients were at channel margins, near islands and channel banks, and close to the river bed.

\section{Scenario A}

The number of juveniles that settled on the river bed declined with distance from the excystment point in all simulations (Figure 4). More than $50 \%$ of juveniles settled within $500 \mathrm{~m}$ of their point of excystment in all simulations except A4, and 90, 80, 77, 35, 86 and $70 \%$ of individuals settled within $1 \mathrm{~km}$ for simulations A1 through A6, respectively. Significantly fewer juveniles settled within $500 \mathrm{~m}$ in simulation A4 because excystment areas were primarily in the channel habitats, where flow velocity was greatest. The modelled likelihood of settling $(\lambda)$ for juvenile A. plicata generally corresponded to the spatial distributions of initial excystment locations, even in A4 when juveniles were assumed to excyst only in channel habitats (Figure 5). Juveniles that excysted in or near the main channel, where velocity gradients were highest (Figure 6c), were more likely to disperse long distances $(>1 \mathrm{~km})$ and have greater variance in dispersal distance (Table III).

Variance in dispersal distance increased when juveniles were assumed to excyst over a greater area of the river (i.e. as juvenile excystment occurred in cells with deeper water) such that $\sigma_{\mathrm{A} 1}^{2}<\sigma_{\mathrm{A} 2}^{2}<\sigma_{\mathrm{A} 3}^{2}$ (Table III). Variation in dispersal distances was greatest when juvenile excystment was only within channel habitats (A4). Variance more than doubled from simulation A3 (when juveniles were released throughout the domain except channel habitats), to A6 (when juvenile excystment was in every cell of the domain including channel habitats). When initial juvenile excystment areas were based on fish data (A5), excystment occurred over less area of the river, but variance in dispersal distance was greater than in A1-A3. The mean magnitude of 2D velocity gradients was greatest in simulation A5 (Table III). In cells where juveniles excysted, velocity gradients were significantly greater $(p<0.001)$ in simulation A5 than in all other simulations. 

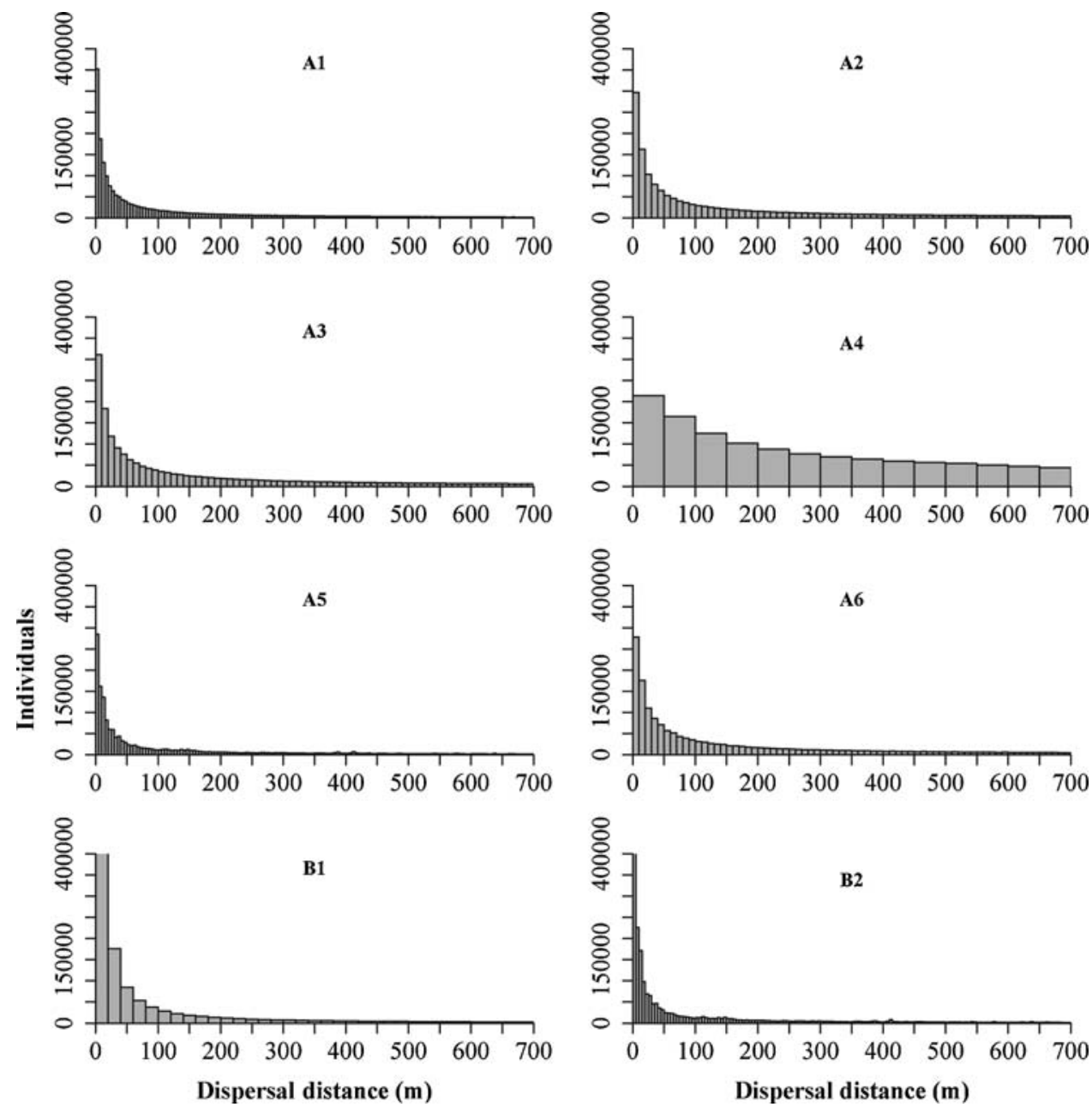

Figure 4. Histograms of juvenile dispersal distance $(\mathrm{m})$ for each simulation in scenario's A and B. A1-A4: juveniles assumed to excyst in cells with water depth $<1.0,<1.5,<2.0$ and $>2.0 \mathrm{~m}$, respecitively; A5: juveniles assumed to excyst in cells at coordinate locations based on data on host fish from the USGS fisheries database (USGS, 2009a); A6: juveniles assumed to excyst in every cell within the domain. B1: juveniles assumed to excyst in cells with water depth $<2.0 \mathrm{~m}$ at all 15 vertical layers of the dispersal mesh; B2: juveniles assumed to excyst in cells based on coordinate locations based on data on host fish from the USGS fisheries database (USGS, 2009a) at all 15 vertical layers of the dispersal mesh

Simulations with excystment location based on fish data (A5) showed some characteristics of each distribution from A1, A2 and A3 (Figure 4). The average water depth of cells where juvenile excystment occurred in A5 was $1.4 \mathrm{~m}, 56 \%$ of juvenile excystment occurred in cells with water $<1 \mathrm{~m}$ deep, and a large proportion of juvenile excystment occurred in cells near the main channel (Figure 3). Skewness of dispersal distances was similar in simulations A5 and A1, but dispersal distances in A5 were significantly greater (difference in location $=3.7 \mathrm{~m}, p<0.001$ ) than in A1. Mean and variance of dispersal distance was greater in simulation A5 than it was in A1, likely because more juvenile excystment occurred in the upper part of the modelled reach and nearer to the main channel in A5 than in A1. Dispersal distance of juveniles in simulation A2 was significantly greater (difference in location $=25 \mathrm{~m}, p<0.001$ ) than in simulation A5, and dispersal distance in A3 was signifi- cantly greater (difference in location $=40 \mathrm{~m}, p<0.001$ ) than in A5. Dispersal distance was significantly greater (difference in location $=8 \mathrm{~m}, p<0.001$ ) in A3 than in A2. A greater number of juveniles excysted near the main channel in simulations $\mathrm{A} 2$ and $\mathrm{A} 3$ than in $\mathrm{A} 5$, and a greater number of juveniles excysted near the main channel in A3 than in A2.

\section{Scenario B}

The number of juveniles that settled decreased with increased distance from the point of excystment in all simulations (Figure 4). Dispersal distance increased significantly $(p<0.001)$ as juvenile excystment occurred higher in the water column (Figure 7b), and changes in dispersal distance with excystment depth were greatest closer to the river bed, where velocity gradients were greater and where downward vertical velocity had a more direct 
A1

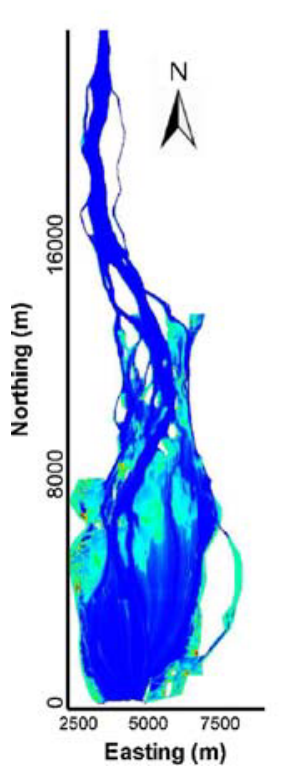

A2

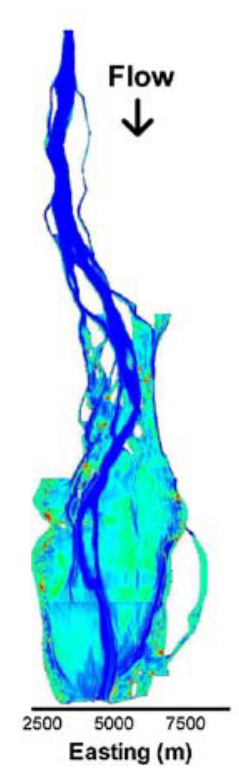

A3

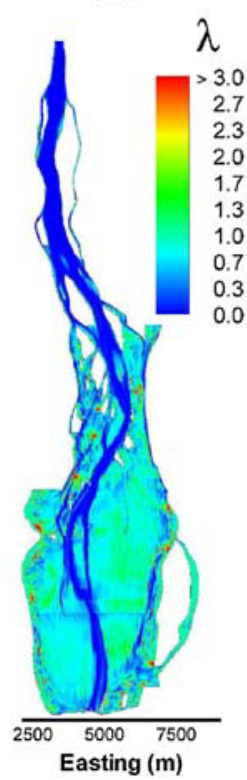

A4

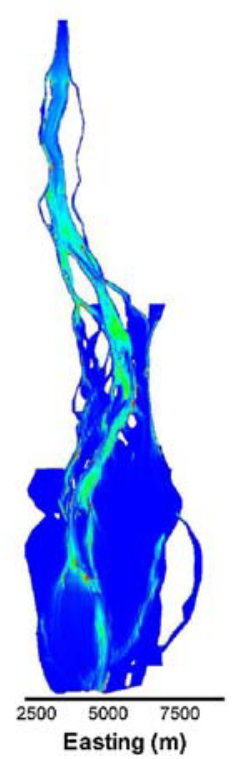

A5

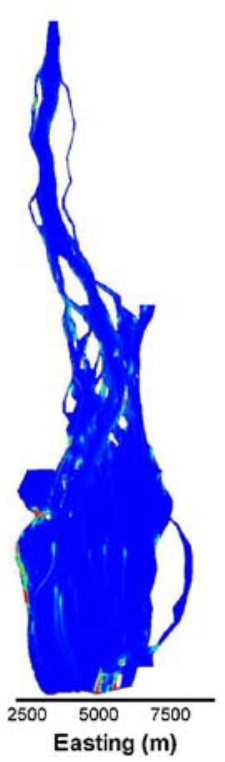

A6

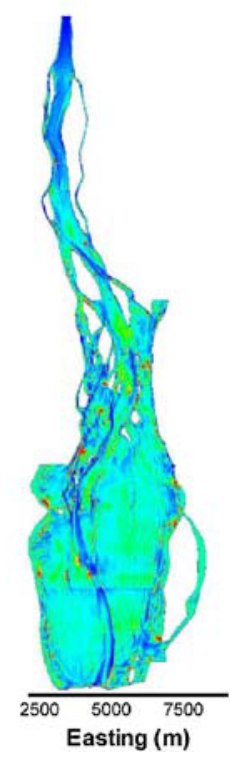

Figure 5. The modelled likelihood of settling $(\lambda)$ for juvenile Amblema plicata in Pool 13 of the Upper Mississippi River. Higher values represent areas where juveniles were more likely to settle in scenario A. A1-A4: juveniles assumed to excyst in cells with water depth $<1.0,<1.5,<2.0$ and $>2.0 \mathrm{~m}$, respecitively; A5: juveniles assumed to excyst in cells based on coordinate locations based on data on host fish from the USGS fisheries database (USGS, 2009a); A6: juveniles assumed to excyst in every cell within the domain.

effect on settling (Figure 7a). Dispersal distance was significantly greater $(p<0.001)$ and variance was greater when juvenile excystment occurred in areas where vertical velocity $(w)$ was positive (indicating an upward velocity, $\left.\mu_{d}=673 \mathrm{~m}, \sigma^{2}=1.4 \times 10^{6}\right)$ than when $w$ was negative $\left(\mu_{d}=492 \mathrm{~m}, \sigma^{2}=1.1 \times 10^{6}\right)$. Changes in dispersal distances with excystment depth $(\Delta d / \Delta h)$ in simulations B2 were 2 to 4 times greater when juvenile excystment occurred near the river bed than when juvenile excystment occurred higher in the water column (Figure 7c). In simulations B1, $\Delta d / \Delta h$ was greatest with excystment near the bed and at depths with greater vertical velocity gradient magnitudes, $W_{g}$, and $\Delta d /$ $\Delta h$ decreased near the water surface corresponding to decreasing $W_{g}$ (Figure 7a, c).

The proportion of the total area within the domain settled by juveniles ranged from 0.87 to 0.90 across all excystment depths. However, the depth of excystment affected the spatial pattern of juvenile settlement in simulations B1 (Figure 8$)$. Over larger scales $(10 \mathrm{~km})$, settling was more uniform throughout the pool when juvenile excystment occurred near the river bed (Figure 8a). At smaller scales $(100 \mathrm{~m})$, juveniles settled nearer their release point when they excysted closer to the river bed $-65 \%$ of juveniles that excysted nearest the bed $(0.1 \%$ of total water depth) settled within $1 \mathrm{~m}$ of their excystment point and $<30 \%$ of juveniles that excysted at $1.0 \%$ of the total water depth settled within $1 \mathrm{~m}$ of their excystment point. Variance in dispersal distance was less when excystment occurred nearer the river bed. Settling distribution was more variable when excystment occurred near the water surface (Figure 8e). Excystment higher in the water column resulted in greater dispersal distances with greater variance; $<1 \%$ of juveniles that excysted at $50 \%$ of total water depth settled within $1 \mathrm{~m}$ of their excystment point and $<0.7 \%$ of juveniles settled within $1 \mathrm{~m}$ when assumed to excyst from the water surface (100\% of total water depth). Juveniles that excysted close to the river bed were less likely to be affected by large scale flow patterns, such as eddies, and more likely to settle as a result of downward vertical velocity (based on the model assumption that juveniles settle on contact with the river bed). The large area of recirculation and the smaller eddies on the lower descending bank of the impounded reach (Figure 6d) had more noticeable effects on the distribution of juvenile settling in the area as juvenile excystment occurred farther from the river bed.

\section{DISCUSSION}

Hydraulically-mediated dispersal of glochidia (Neves and Widlak, 1987; Zimmerman and Neves, 2002) or excysted juveniles (Morales et al., 2006a) has been occasionally considered, but most studies of host fish-mussel interactions implicitly or explicitly consider host fish movement of primary importance for dispersal for mussels. Our simulations suggest that after excystment from the host fish, the combined effects of the magnitude of velocity and velocity gradients where juveniles excyst strongly influence dispersal distance. 


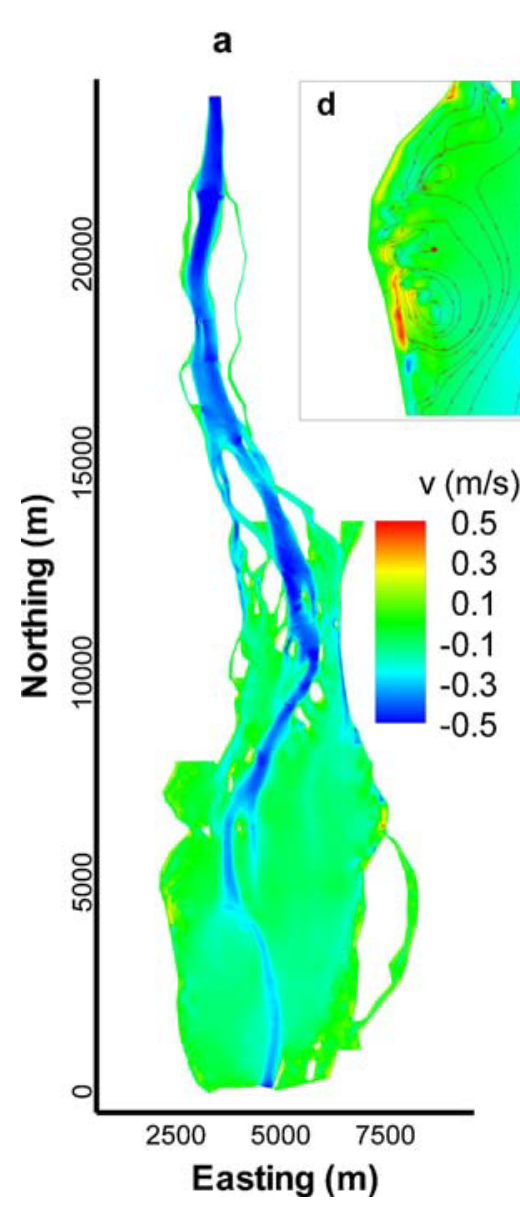

b

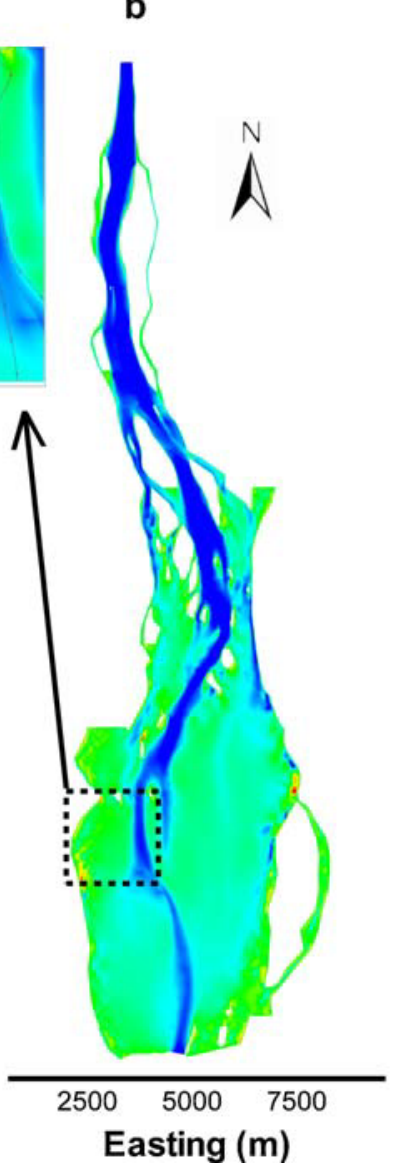

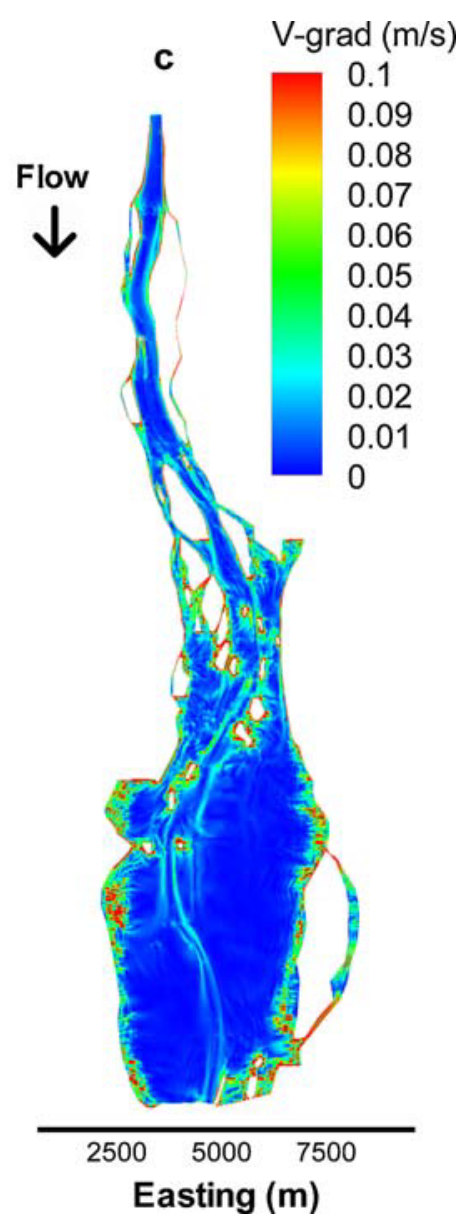

Figure 6. Near bed 2D velocity magnitude $\left(\mathrm{V}, \mathrm{m} \mathrm{s}^{-1}\right.$ ) near the river bed in Pool 13 of the Upper Mississippi River (a), 2D velocity magnitude at $50 \%$ of the total depth (b) and 2D velocity gradients (c) estimated from CFD simulations. Negative velocities are in the direction of flow, positive velocity is upstream flow. Areas where contour colours change have steep velocity gradients. The CFD model predicts a large area of recirculation on the right bank (facing downstream) of the impounded area (d). Lines in (d) represent streamtraces that show trajectories that juveniles will take when moving with flow in the absence of turbulence.

Table III. Mean $\left(\mu_{d}\right)$ and variance $\left(\sigma_{d}^{2}\right)$ of juvenile dispersal distances, skewness of dispersal distance distribution $\left(S_{d}\right)$, and mean $\left(\mu_{g}\right)$ and variance $\left(\sigma_{g}^{2}\right)$ of the magnitude of the $2 \mathrm{D}$ velocity gradients $\left(V_{g}\right)^{\mathrm{a}}$ in cells where juveniles were assumed to excyst for simulations in scenario A. Juveniles assumed to excyst in cells with water depth $<1.0$ (A1), $<1.5$ (A2), $<2.0 \mathrm{~m}$ (A3) and $>2.0 \mathrm{~m}$ (A4); juveniles assumed to excyst in cells based on spatial locations of host fish from the USGS fish database (A5) (USGS, 2009b); and in every cell within the domain (A6)

\begin{tabular}{|c|c|c|c|c|c|c|}
\hline \multirow[b]{2}{*}{ Scenario } & \multirow[b]{2}{*}{ Initial condition } & \multicolumn{3}{|c|}{ Juvenile dispersal distance } & \multicolumn{2}{|c|}{ Velocity gradients } \\
\hline & & $\mu_{d}$ & $\sigma_{d}^{2}$ & $S_{d}$ & $\mu_{g}$ & $\sigma_{g}^{2}$ \\
\hline A1 & Depth $<1 \mathrm{~m}$ & 363 & $8.5 \mathrm{e}+05$ & 4.5 & 0.030 & 0.0022 \\
\hline $\mathrm{A} 2$ & Depth $<1.5 \mathrm{~m}$ & 621 & $1.3 \mathrm{e}+06$ & 3.0 & 0.020 & 0.0015 \\
\hline A3 & Depth $<2 \mathrm{~m}$ & 681 & $1.4 \mathrm{e}+06$ & 2.9 & 0.019 & 0.0014 \\
\hline A4 & Depth $>2 \mathrm{~m}$ & 2207 & $7.9 \mathrm{e}+06$ & 2.2 & 0.018 & 0.0007 \\
\hline A5 & Fish data & 500 & $1.5 \mathrm{e}+06$ & 4.5 & 0.049 & 0.0029 \\
\hline A6 & All cells & 1074 & $3.6 e+06$ & 3.3 & 0.019 & 0.0012 \\
\hline
\end{tabular}

${ }^{\mathrm{a}} V_{g}=\left[(\Delta u / \Delta y)^{2}+(\Delta v / \Delta x)^{2}\right]^{1 / 2}$ 

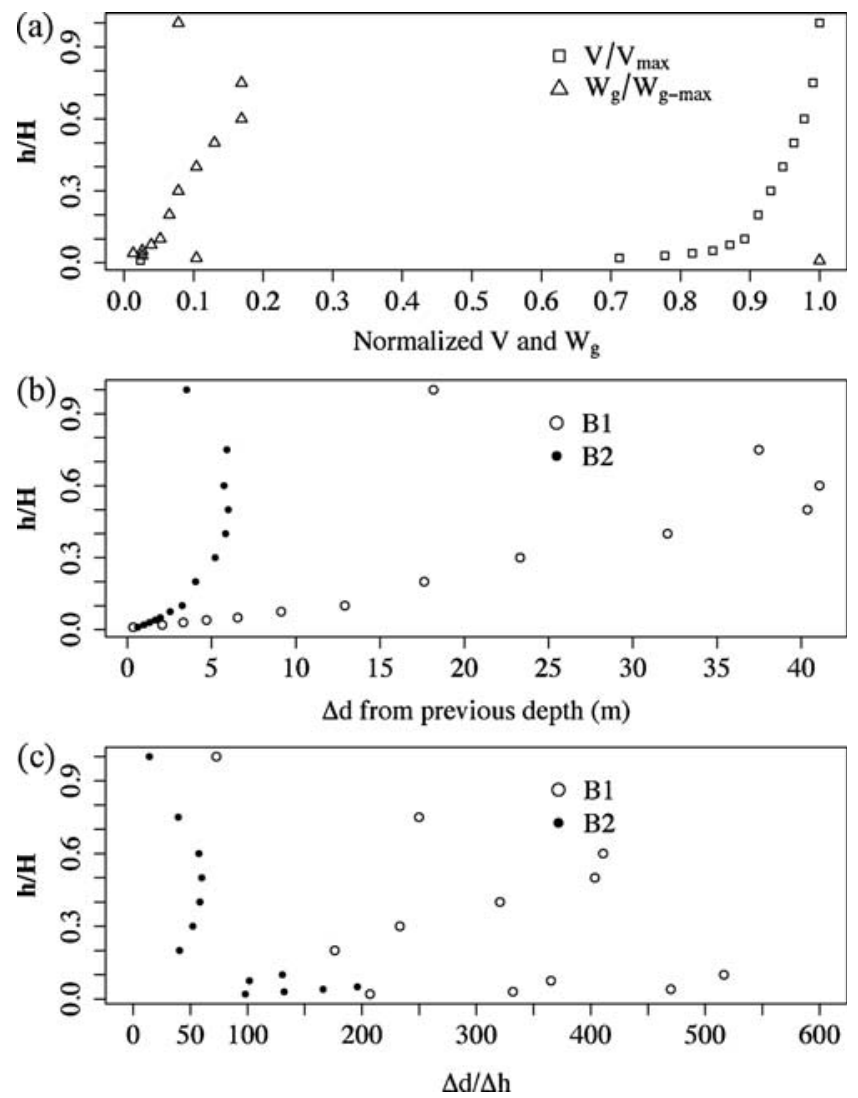

Figure 7. (a) Average 2D velocity magnitude $\left(V, \mathrm{~m} \mathrm{~s}^{-1}\right)$ at each excystment depth normalized to the maximum $V$ (at the water surface, $\square$ ) and the median magnitude of the $2 \mathrm{D}$ velocity gradient $\left(\mathrm{W}_{\mathrm{g}}, \mathrm{ms}^{-1} \mathrm{~m}^{-1}\right)$ at each excystment depth normalized to the maximum $W_{g}$ near the river bed $(\Delta)$. (b) Increase in juvenile dispersal distance (m) from the previous depth of excystment in simulations B1 $(\bigcirc)$, when juvenile excystment occurred in all cells with a water depth $<2 \mathrm{~m}$, and simulations B2 (O), when juvenile excystment location was based on fish presence data from the USGS fish data (USGS, 2009a). (c) Change in dispersal distance with change in excystment depth $(\Delta \mathrm{d} / \Delta \mathrm{h})$ in simulations B1 and B2. Depth of excystment $(h)$ is normalized to the total water depth $(H)$ in a cell

Juvenile dispersal distance was most variable in environments with higher velocity and high gradients in velocity, such as along channel margins, near the river bed, or where effects of local bed morphology (e.g. wing dams) may cause relatively large changes in hydraulics. Ecological processes that effect mussel populations have been shown to be dependent upon scales of interaction (Vaughn and Spooner, 2006), and the importance of host fish location at the time of juvenile excystment may be dependent on small scale interactions (m) with hydraulics in areas of complex flows. Upward vertical velocities significantly increased dispersal distances, and hydraulic conditions near the bed are significantly affected by small-scale physical features of the river bed and vegetation. Local hydraulic patterns resulting from complex bed morphology and flow altering objects (e.g. woody debris) lead to complex 3D flow patterns, vertical velocities, and cause distortion in the local velocity field that result in sharp velocity gradients. More complex hydraulics occur in channel border habitats where gradients in velocity are relatively steep in the transition zone from higher flow in the main channel to areas of lower flow along channel margins. In these environments, depth of host fish at the time of juvenile excystment may be relatively less important unless excystment occurs very near the river bed. Juveniles that excyst along the main channel border, where velocity gradients are steep, are more likely to become entrained in higher velocity flow in the main channel and disperse greater distances than juveniles that excysted in shallow or impounded water.

Impounded waters in large rivers are characterized by tranquil flow with relatively uniform hydraulic conditions and without large gradients in velocity. Impoundments created by the construction of hydraulic structures are a significant part of most river systems in the US. Dams affect mussel dispersal principally by limiting host fish movements (Watters, 2000; Brainwood et al., 2008) and perhaps by blocking downstream dispersal of settling juveniles. Adult mussel distributions can be significantly altered downstream from impoundments (Vaughn and Taylor, 1999), and our results suggest that upstream of a dam, within the resulting impounded area, settling is predominantly local and source areas of juveniles in impounded habitats are likely also local. Juveniles that excyst in impounded areas will likely settle nearby (within $500 \mathrm{~m}$ in Pool 13 of the UMR) with increased dispersal distance as juvenile excystment occurs nearer the water surface. There is little hydraulic interaction in impounded areas at small scales, and at larger scales $(>100 \mathrm{~m})$ less uniform settling suggests that spatial patterns were dependent on patterns of flow. For instance, if juveniles excyst from their host fish in eddies, dispersal distance will be relatively short but become more variable when excystment occurs farther from the river bed.

As a consequence of impoundment, there will likely be a reduction in upstream sources of juveniles that would have settled in the area prior to impoundment. In contrast, juveniles settling along channel borders are more likely to have excysted from their host fish farther upstream, and settling distribution may depend more on upstream hydraulics (Daraio et al., 2010b). This has implications for connectivity of metapopulations and gene flow, especially within pools and among pools in the UMR. Metapopulations in impounded areas may be relatively isolated at most flow rates limiting gene flow and migration, and high flow rates may have significant effects on connectivity in large rivers. Such downstream linkages might be more prevalent in the lower navigation pools in the UMR, which are substantially more channelized than upper reaches and contain few backwaters and lentic impounded areas (USACE, 2000). 
a

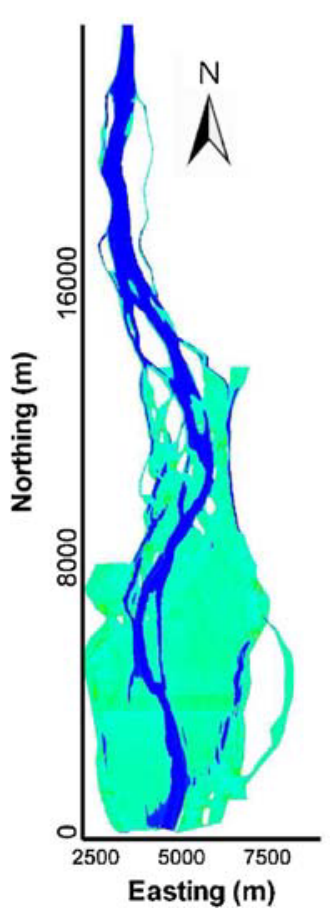

b

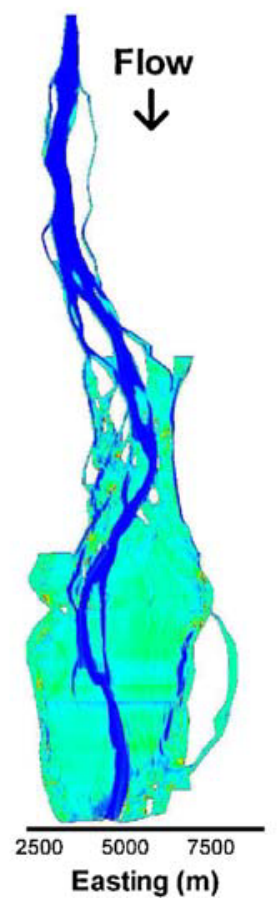

C

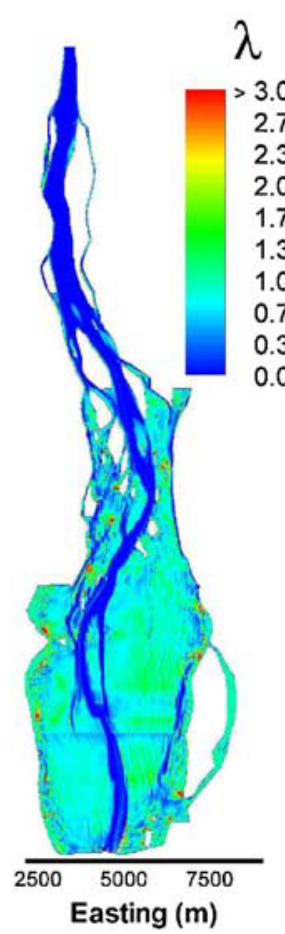

d

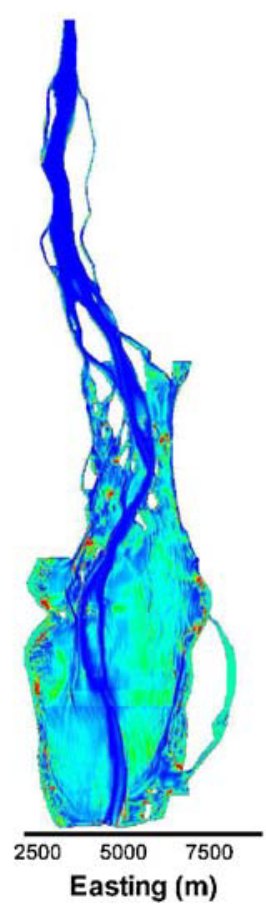

e

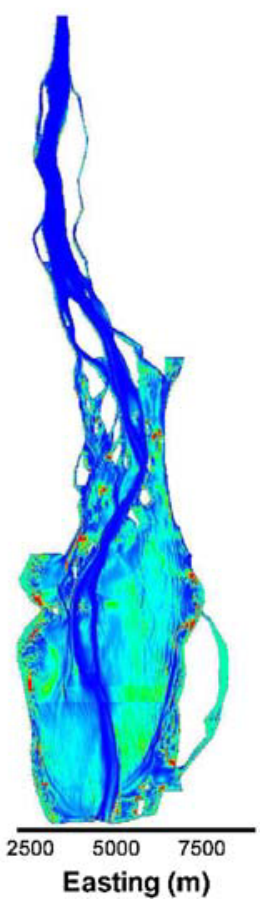

Figure 8. The modelled likelihood of settling $(\lambda)$ for juvenile Amblema plicata in Pool 13 of the Upper Mississippi River. Higher values represent areas where juveniles are more likely to settle in simulations B1. Juveniles were assumed to excyst initially (a) near the bed (0.1\% of the total depth in cell), at (b) $5 \%$, (c) $10 \%$ and (d) $50 \%$ of the total depth, and (e) at the water surface, throughout the entire domain in cells with depth $<2 \mathrm{~m}$.

Results showing the sensitivity of the location of excystment on juvenile dispersal suggest that habitat preferences of host fish likely influence where juveniles settle across the river bed. Flow patterns and high velocity gradients in side channels and main channel border areas may influence juvenile dispersal due to their effects on host fish distributions. These areas might be particularly important as reservoirs of host fish because they contain substantially higher fish biomass than backwaters or the main navigation channel (Gutreuter et al., 2006). Juvenile dispersal distances may be more variable for mussel species with a host that prefers an environment along channel margins than a host that prefers more tranquil water or habitats with vegetation. Fish locate themselves and move within local flow fields in rivers based on hydraulic strain sensed through their lateral line system (Nestler et al. 2008), and in high gradient environments fish may be more likely to capture prey drifting downstream in areas of higher flow (Hayes and Jowett, 1994). For host fish that prefer habitats along channel margins, near other areas of greater conveyance, or near channel obstructions causing velocity gradients, modest changes in location can have a strong effect on downstream dispersal of juvenile mussels. Juveniles that excyst from host fish in these environments would be more likely to become entrained in relatively high velocity flow, disperse greater distances, and be distributed over a more variable area of the river. Wing dams, closing dikes and other anthropogenic modifications common to main channel border and side channels of the UMR and other rivers could subsequently influence dispersal due to altered distribution patterns of fish (Barko et al., 2004) and large changes in flow patterns.

Fremling et al. (1989) list 193 fish species in 27 families for the Mississippi River, ranging from rheophilic to limnophilic species, many of which serve as host fish for one or more of the various mussel species present in the river. Our example, A. plicata, is a host generalist using at least 12 species of fish that typically inhabit a wide range of habitats in the river. The majority of the host species are centrarchids, which are common in the UMR, and are typically associated with vegetation and shallow, slowmoving waters (Becker 1983; Dewey et al., 1997). In habitats such as backwaters, sloughs and impounded areas where A. plicata is abundant (Bartsch et al., 2010), hydraulically mediated dispersal is expected to be low. However, other host fish species such as sauger and flathead catfish are often associated with flowing areas within the main channel border and side channels of the Mississippi 
River (Becker, 1983) and undoubtedly contribute to distributions of A. plicata in those flowing habitats. Excysted juveniles from those fish species would be expected to have substantially higher dispersal distances. The paucity of backwater habitat and centrarchids (Gutreuter, 2004) in downstream areas such as the undammed Middle Mississippi River suggests that A. plicata may have higher overall hydraulic dispersal in that area in comparison to the upper impounded reaches of the Upper Mississippi River. Moreover, our results suggest that some mussel species that depend entirely on rheophilic host fish could have greater downstream dispersal than mussel species that depend on limnophilic fish hosts. For example, the hickorynut mussel (Obovaria olivaria) and the fawnsfoot mussel (Truncilla donaciformis), which typically inhabit channel areas with high flow, are host specialists that use stongly rheophilic fishes including the shovelnose sturgeon (Scaphirynchus platorynchus) and freshwater drum (Aplodinotus grunniens). These mussel species might be expected to have larger spatial linkages for metapopulations not only because their fish hosts are potamodromous (Wilcox et al., 2004), but also because hydraulic dispersal after excystment is more likely to be large.

Relationships between mussel communities and host fish can be affected by interactions with reach morphology, streamsize, and hydraulics (Haag and Warren, 1998; Gangloff and Feminella, 2007). Hydrologic conditions affect dispersal by altering hydraulic patterns and current velocities, and can also affect host fish distributions. Riverine fish are responsive to temporal and spatial patterns in flow velocity (Bain et al., 1988; Wildhaber et al., 2003). In the UMR, movements of centrarchids into the main channel border often occurs in the summer and autumn during periods of low discharge, possibly in response to food resources and declining dissolved oxygen or anoxia in quiescent backwaters (Gutreuter et al., 2010). Even rheophilic species such as shovelnose sturgeon, which often inhabit the main navigation channel (Dettmers et al., 2001; Gutreuter et al., 2006), move laterally into channel borders and seek refuge behind channel training structures (e.g. wingdams) during periods of high discharge (Hurley et al., 1987; Curtis et al., 1997). It is likely that host fish use a variety of habitats, and dynamic interactions between host fish and flow hydraulics presumably affect juvenile settling distributions. These interactions are further complicated by the potential for parasite induced changes of host fish behaviour. An infected fish may have reduced stamina (Jog and Watve, 2005) and tire more easilythis may lead the host fish to seek out tranquil flow, even if it's preferred habitat is within higher velocity waters. This behaviour could directly impact juvenile dispersal distances and settling distributions.

The high degree of uncertainty regarding the distribution of a host fish at the time of juvenile excystment and model assumptions in this research preclude the general use of our model for predictions of juvenile mussel distributions and limits the ability to directly validate model results. For instance, our simulations isolate the effects of hydraulics in the water column and do not account for processes occurring near the river bed. However, the model correctly describes the physics of the dispersal process, and it can be used to locate areas where juveniles are likely to settle given a population size and distribution of host fish species for conservation purposes. It can also be used to locate areas upstream of a target habitat where (and what size) populations of host fish are required to ensure that enough juveniles settle to maintain or seed the area. (Daraio et al. (2010b) discuss some other potential future research and conservation applications.) The scale of application of the dispersal model is dependent primarily upon the resolution of the CFD model, and areas of future study include examining in more detail the effects of channel morphology and hydraulics on juvenile settlement patterns and unionid dispersal.

Model predictions can be improved with valid estimations of host fish distributions and measures of bed shear stress. Recent research in the UMR indicates that bed shear stress is important in predicting the presence of adult mussels (Steuer et al., 2008; Zigler et al., 2008). In another reach of the UMR, Daraio et al. (2010a) have shown that bed shear stress can have significant effects on juvenile settling distributions with reductions in total area settled from 40 to $98 \%$, depending on flow rate. Morales et al. (2006a) have shown that relative shear stress (a function of bed shear stress and substrate type) significantly affected settling distributions of juvenile mussels.

Combining insights from Morales et al. (2006a), Daraio et al. (2010a), and Daraio et al. (2010b) with our results, the processes controlling juvenile dispersal are becoming more clear. Our results suggests that the magnitude of velocity and velocity gradients where juveniles excyst strongly influence dispersal distance, that most juvenile mussels will first contact the substrate within about $500 \mathrm{~m}$ of its location of excystment from its host in the UMR, and that hydraulically mediated dispersal $>500 \mathrm{~m}$ is more likely to occur in deep channels with high flow. Collectively, this body of research suggests that host fish distribution, excystment depth, hydraulic conditions at the location of excystment, water column hydraulics, and bed shear stress, all of which likely vary with flow rate, interact in various ways to affect dispersal of juvenile mussels in a large river.

\section{ACKNOWLEDGEMENTS}

This research was funded by IIHR Hydroscience and Engineering. Authors thank George Constantinescu, Keri Horn- 
buckle, Lee Hastie, David Strayer, Mike Gangloff and two anonymous reviewers for comments on earlier drafts of the manuscript. Product names are provided for informational purposes only and do not represent an endorsement by the US Geological Survey.

\section{REFERENCES}

Amyot JP, Downing JA. 1998. Locomotion in Elliptio complanata (Mollusca: Unionidae): a reproductive function? Freshwater Biology 39: $351-358$.

Bain MB, Finn JT, Booke HE. 1988. Streamflow regulation of fish community structure. Ecology 69: 382-392.

Balfour DL, Smock LA. 1995. Distribution, age structure, and movements of the freshwater mussel Elliptio complanata (Mollusca: Unionidae): in a headwater stream. Journal of Freshwater Ecology 10: 255-268.

Barko VA, Herzog DP, Hrabik RA, Scheibe JS. 2004. Relationship among fish assemblages and main-channel-border physical habitats in the unimpounded upper Mississippi River. Transactions of the American Fisheries Society 133: 371-384.

Bartsch MR, Zigler SJ, Newton TJ, Sauer JS. 2010. Influence of shell morphology on distributions of unionids in the Upper Mississippi River. Journal of Molluscan Studies 76: 67-76.

Becker GC. 1983. Fishes of Wisconsin. The University of Wisconsin Press: Madison, WI.

Brainwood M, Burgin S, Byrne M. 2008. The impact of small and large impoundments on freshwater mussel distribution in the HawkesburyNepean River, Southeastern Australia. River Research and Applications 24: $1325-1342$. DOI: $10.1002 /$ rra. 1087

Chick JH, Ickes BS, Pegg MA, Barko VA, Hrabik RA, Herzong DP. 2005. Spatial structure and temporal variation of fish communities in the Upper Mississippi River System. LTRMP Technical Report 2005-T004.

Crimaldi JP, Thompson JK, Rosman JH, Lowe RJ, Koseff JR. 2002. Hydrodynamics of larval settlement: the influence of turbulent stress events at potential recruitment sites. Limnology and Oceanography 47: 1137-1151.

Curtis GL, Ramsey LS, Scarnecchia DL. 1997. Habitat use and movements of shovelnose sturgeon in Pool 13 of the upper Mississippi River during extreme low flow conditions. Environmental Biology of Fishes 50: 175182.

Daraio JA, Weber LJ, Newton TJ. 2010a. Hydrodynamic modeling of juvenile mussel dispersal in a large river: the potential effects of bed shear stress and other hydraulic parameters. Journal of the North American Benthological Society 29: 838-851. DOI: 10.1899/09-118.1

Daraio JA, Weber LJ, Newton TJ, Nestler JM. 2010b. A methodological framework for integrating computational fluid dynamics and ecological models applied to juvenile freshwater mussel dispersal in the Upper Mississippi River. Ecological Modelling 221: 201-214. DOI: 10.1016/ j.ecolmodel.2009.10.008

Dettmers JM, Gutreuter S, Wahl DH, Soluk DA. 2001. Patterns in abundance of fishes in main channels of the Upper Mississippi River. Canadian Journal of Fisheries and Aquatic Science 58: 933-942. DOI: $10.1139 /$ cjfas-58-5-933

Dewey MR, Richardson WB, Zigler SJ. 1997. Patterns of foraging and distribution of bluegill sunfish in a Mississippi River backwater: influence of macrophytes and predation. Ecology of Freshwater Fish 6: 8-15.

Fremling CR, Rasmussen JL, Sparks RE, Cobb SP, Bryan CF, Claflin TO. 1989. Mississippi River fisheries: a case history. In Proceedings of the International Large River Symposium (LARS), Dodge DP (ed.). Canadian Special Publication of Fisheries and Aquatic Sciences 106, Department of Fisheries and Oceans: Ottawa; 309-351.
Gangloff MM, Feminella JW. 2007. Stream channel geomorphology influences mussel abundance in southern Appalachian streams, USA. Freshwater Biology 52: 64-74. DOI: 10.1111/j.1365-2427.2006.01673.x

Guha A. 2008. Transport and deposition of particles in turbulent and laminar flow. Annual Review of Fluid Mechanics 40: 311-341. DOI: 10.1146/ annurev.fluid.40.111406.102220

Gutreuter S. 2004. Challenging the assumption of habitat limitation: an example from centrarchid fishes over an intermediate spatial scale. River Research and Applications 20: 413-425. DOI: 10.1002/rra.757

Gutreuter S, Burkhardt R, Lubinski K. 1995. Long Term Resource Monitoring Program Procedures: Fish Monitoring. National Biological Service, Environmental Management Technical Center: Onalaska, WI.

Gutreuter S, Vallazza JM, Knights BC. 2006. Persistent disturbance by commercial navigation alters the relative abundance of channel-dwelling fishes in a large river. Canadian Journal of Fisheries and Aquatic Sciences 63: 2418-2433. DOI: 10.1139/F06-129

Gutreuter S, Vallazza JM, Knights BC. 2010. Lateral distribution of fishes in the main-channel trough of a large floodplain river: implications for restoration. River Research and Applications 26: 619-635. DOI: 10.1002/ rra.1271

Haag WR, Warren MLJJr. 1998. Host fishes and reproductive biology of 6 freshwater mussel species from the Mobile Basin, USA. Journal of the North American Benthological Society 16: 576-585.

Hart DD, Finelli CM. 1999. Physical-biological coupling in streams: the pervasive effects of flow on benthic organisms. Annual Review of Ecology and Systematics 30: 363-395. DOI: 10.1146/annurev.ecolsys.30.1.363

Hayes JW, Jowett IG. 1994. Microhabitat models of large drift-feeding brown trout in three New Zealand rivers. North American Journal of Fisheries Management 14: 710-725. DOI: 10.1577/1548- 8675(1994)014

Hurley ST, Hubert WA, Nickum JG. 1987. Habitats and movements of shovelnose sturgeons in the upper Mississippi River. Transactions of the American Fisheries Society 116: 655-662. DOI: 10.1577/15488659(1987)116

Jog M, Watve M. 2005. Role of parasites and commensals in shaping host behavior. Current Science 89: 1184-1191.

Johnson BL, Jennings CA. 1998. Habitat associations of small fishes around islands in the Upper Mississippi River. North American Journal of Fisheries Management 18: 327-336. DOI: 10.1577/1548- 8675(1998)018

Lai YG, Weber LJ, Patel VC. 2003a. Nonhydrostatic three-dimensional model for hydraulic flow simulation. I: Formulation and verification. Journal of Hydraulic Engineering-ASCE 129: 196-205. DOI: 10.1061/ (ASCE)0733-9429(2003)

Lai YG, Weber LJ, Patel VC. 2003b. Nonhydrostatic three-dimensional model for hydraulic flow simulation. II: Validation and application. Journal of Hydraulic Engineering-ASCE 129: 206-214. DOI: 10.1061/ (ASCE)0733-9429(2003)

Lefevre G, Curtis WC. 1910. Reproduction and parasitism in the unionidae. Journal of Experimental Zoology 9: 79-116.

Lydeard C, Cowie RH, Ponder WF, Bogan AE, Bouchet P, Clark SA, Cummings KS, Frest TJ, Gargominy O, Herbert DG, Hershler R, Perez KE, Roth B, Seddon M, Strong EE, Thompson FG. 2004. The global decline of nonmarine mollusks. Bioscience 54: 321-330. DOI: 10.1641/ 0006- 3568(2004)054

Minshall GW, Petersen RC, Nimz CF. 1985. Species richness of different size from the same drainage basin. The American Naturalist 125: 16-38.

Morales Y, Weber LJ, Mynett AE, Newton TJ. 2006a. Effects of substrate and hydrodynamic conditions on the formation of mussel beds in a large river. Journal of the North American Benthological Society 25: 664-676. DOI: $10.1899 / 0887-3593(2006) 25$

Morales Y, Weber LJ, Mynett AE, Newton TJ. 2006b. Mussel dynamics model: a hydroinformatics tool for analyzing the effects of different stressors on the dynamics of freshwater mussel communities. Ecological Modelling 197: 448-460. DOI: 10.1016/j.ecolmodel.2006.03.018 
Nestler JM, Goodwin RA, Smith DL, Anderson JJ, Li S. 2008. Optimum fish passage and guidance designs are based on hydrogeomorphology of natural rivers. River Research and Applications 24: 148-168. DOI: 10.1002/rra. 1056

Neves RJ, Widlak JC. 1987. Occurrence of glochidia in stream drift and on fishes of the upper North Fork Holston River, Virginia. American Midland Naturalist 119: 111-120.

Newton TJ, Woolnough DA, Strayer DL. 2008. Using landscape ecology to understand and manage freshwater mussel populations. Journal of the North American Benthological Society 27: 424-439. DOI: 10.1899/07076.1

North EW, Schlag Z, Hood RR, Li M, Zhong L, Gross T, Kennedy VS. 2008. Vertical swimming behavior influences the dispersal of simulated oyster larvae in a coupled particle-tracking and hydrodyanmic model of the Chesapeake Bay. Marine Ecology Progress Series 359: 99-115. DOI: 10.3354/meps07317

Parmalee PW, Bogan AE. 1998. The Freshwater Mussels of Tennessee. University of Tennessee Press: Knoxville, TN; 328.

Rashleigh B. 2008. Nestedness in riverine mussel communities: patterns across sites and fish hosts. Ecography 31: 612-619. DOI: 10.1111/j.09067590.2008.05300.x

Rashleigh B, DeAngelis DL. 2007. Conditions for coexistence of freshwater mussel species via partitioning of fish host resources. Ecological Modelling 201: 171-178.

Schwalb AN. 2009. Host infection strategies determine dispersal abilities in freshwater mussels (Bivalvia: Unionidae). Ph.D. Dissertation, University of Guelph: Ontario, Canada.

Schwalb AN, Pusch MT. 2007. Horizontal and vertical movements of unionid mussels in a lowland river. Journal of the North American Benthological Society 26: 261-272. DOI: 10.1899/08873593(2007)26

Steuer JJ, Newton TJ, Zigler SJ. 2008. Use of complex hydraulic variables to predict the distribution and density of unionids in a side channel of the Upper Mississippi River. Hydrobiologia 610: 67-82. DOI: 10.1007/ s10750-008-9423-z

Strayer DL. 2008. Freshwater Mussel Ecology: A Multifactor Approach to Distribution and Abundance. University of California Press: California.

Strayer DL, Downing JA, Haag WR, King TL, Layzer JB, Newton TJ, Nichols SJ. 2004. Changing perspectives on pearly mussels, North America's most imperiled animals. Bioscience 54: 429-439. DOI: 10.1641/0006-3568(2004)054

USACE (US Army Corps of Engineers). 2000. Upper Mississippi River System Habitat Needs Assessment: Summary Report 2000, US Army Corps of Engineers, St. Louis District: St. Louis, Missouri.

USGS. 2009a. Upper Midwest Environmental Sciences Center: GIS DataPool 13-Upper Mississippi River. Available at: http://www.umesc. usgs.gov/rivers/upper_mississippi/reach_1/ pool_13/p13_gis _data.html\#bath

USGS. 2009b. Upper Midwest Environmental Sciences Center-Fisheries Data. Available at: http://www.umesc.usgs.gov/data_library/fisheries/ fish_page.html

Vaughn CC. 1997. Regional patterns of mussel species distributions in North American rivers. Ecography 20: 107-115.

Vaughn CC, Spooner DE. 2006. Scale-dependent associations between native freshwater mussels and invasive Corbicula. Hydrobiologia 568 : 331-339. DOI: 10.1007/s10750-006-0210-4

Vaughn CC, Taylor CM. 1999. Impoundments and the decline of freshwater mussels a case study of an extinction gradient. Conservation Biology 13: 912-920.

Vaughn CC, Taylor CM. 2000. Macroecology of a host-parasite relationship. Ecography 23: 11-20.

Villella RF, Smith DR, Lemarié DP. 2004. Estimating survival and recruitment in a freshwater mussel population using mark-recapture techniques. American Midland Naturalist 151: 114-133.
Watters GT. 1992. Unionids, fishes, and the species-area curve. Journal of Biogeography 19: 481-490.

Watters GT. 1996. Small dams as barriers to freshwater mussels (Bivalvia, Unionidae) and their hosts. Biological Conservation 75: 79-85.

Watters GT. 2000. Freshwater mussels and water quality: a review of the effects of hydrologic and instream habitat alteration. In Proceedings of the First Freshwater Mollusk Conservation Society Symposium, 1999; 261-274.

Wilcox D, Stefanik E, Kelner D, Cornish M, Hodgins I, Zigler S, Johnson B. 2004. Improving fish passage through navigation dams in the Upper Mississippi River System. US Army Corps of Engineers, Upper Mississippi River-Illinois Waterway Navigation Study, ENV Report 54, 181.

Wildhaber ML, Laberson PJ, Galat DL. 2003. A comparison of measures of riverbed form for evaluating distributions of benthic fishes. North American Journal of Fisheries Management 23: 543-557. DOI: 10.1577/ 1548-8675(2003)023

Zigler SJ, Newton TJ, Steuer JJ, Bartsch MR, Sauer JS. 2008. Importance of physical and hydraulic characteristics to unionid mussels: a retrospective analysis in a reach of large river. Hydrobiologia 598: 343-360. DOI: 10.1007/s10750-007-9167-1

Zimmerman LL, Neves RJ. 2002. Effects of temperature on duration of viability for glochidia of freshwater mussels (Bivalvia: Unionidae). American Malacological Bulletin 17: 31-35.

\section{APPENDIX}

\section{Hydrodynamic modelling and particle tracking}

A 3D non-uniform structured mesh of the modelled reach was generated with the commercial software Gridgen (Pointwise, Ft. Worth, Texas, USA) using bathymetric data (USGS, 2009b). A fixed sloping water surface was used as the free surface boundary. Water surface elevations were calculated using a HEC-RAS model set up by the US Army Corps of Engineers for pool 13. The flow field was simulated using the Reynolds-Averaged Navier-Stokes (RANS) equations using a $\mathrm{k}-\varepsilon$ turbulence model with the CFD model U²RANS developed by Lai et al. (2003a, 2003b). Juvenile mussels were modelled using stochastic Lagrangian particle tracking through a 3D flow field as output from the CFD model. A Markov chain random walk model, with a basic form of the Langevin equation, was used to model particle movement assuming stationary homogeneous isotropic turbulence (Guha, 2008). Homogeneous isotropic turbulence is uniform in all 3 Cartesian coordinates, and it has a constant mean through time (stationary).

Particle trajectories were found using the following.

$$
\begin{gathered}
x_{t+\Delta t}=x_{t}+\left(u_{c}+u^{\prime}\right) \Delta t \\
y_{t+\Delta t}=y_{t}+\left(v_{c}+v^{\prime}\right) \Delta t \\
z_{t+\Delta t}=z_{t}+\left(w_{c}+w^{\prime}+\omega\right) \Delta t
\end{gathered}
$$

where $x, y$, and $z$ are Cartesian coordinates $(\mathrm{m})$ of the particle (juvenile mussel), $u_{c}, v_{c}$, and $w_{c}$ are components of velocity and $u^{\prime}, v^{\prime}$, and $w^{\prime}$ are turbulent fluctuations $\left(\mathrm{m} \mathrm{s}^{-1}\right)$ in a cell in the $x, y$, and $z$ direction respectively at time $t$, and $\Delta t$ is the 
time step (s), and $\omega$ is the fall velocity $\left(\mathrm{m} \mathrm{s}^{-1}\right)$ given by Stoke's Law as discussed in the body of the paper.

Turbulent fluctuations are represented as a function of turbulent kinetic energy $(k)$ in each cell,

$$
u_{t}^{\prime}=v_{t}^{\prime}=w_{t}^{\prime}=f\left(k_{c}\right)=\alpha_{t} \sqrt{\frac{2 k_{c}}{3}}
$$

where the constant of proportionality $\alpha_{t}$ is a Gaussian random variable with $\mu=0$ (since time averaged fluctuations $\mathrm{u}^{\prime}=0 \mathrm{~m} \mathrm{~s}^{-1}$ ), and $\sigma^{2}=1$, which is different at every time step $(t)$ and the same in $x, y$, and $z$ for isotropic homogeneous turbulence. 